\title{
Parlando Rubato \\ György Kurtág and Hungarian Folk Music
}

\author{
Anna DALOS \\ Institute for Musicology, Research Centre for the Humanities \\ Táncsics Mihály u. 7., H-1014 Budapest, Hungary \\ Email: dalos.anna@btk.mta.hu
}

Received: August 2018; accepted: October 2018

\begin{abstract}
This study focuses on the use of the parlando rubato style of Hungarian folk music in György Kurtág's compositions. Kurtág applies the terms parlando, rubato, and molto rubato several times, and these designations always refer to a clearly defined meaning in his compositions, connected to "Hungarianness" and sexuality. This study aims to reveal these meanings, aided by Kurtág's compositional sketches and notes preserved in the Paul Sacher Foundation in Basel, as well as through analysis of vocal works such as the Four Songs (op. 11), S. K. - Remembrance Noise (op. 12), Attila József Fragments (op. 20), Seven Songs (op. 22), Eight Choruses (op. 23), Kafka Fragments (op. 24), and Three Old Inscriptions (op. 25).
\end{abstract}

Keywords: György Kurtág, Hungarianness, Hungarian folk music, compositional sketches

Recollecting his youth, which was shared with György Ligeti, in 1993 György Kurtág recounted his compulsory folk music studies at the Liszt Academy of Music, Budapest as follows:

Hungarian folk music was [a] compulsory [subject] for all students at the Academy. Kodály was very strict while teaching and examining, but he explained little. In a few sentences Ligeti explained to Márta and me the main types of Hungarian folk song: six, seven, or eight syllables (and their derivatives), and how you can recognize them by cadence rhythms. ${ }^{1}$

1. György Kurtág. Three Interviews and Ligeti Homages, ed. by Bálint András VARGA (Rochester, NY: Rochester University Press, 2009), 99. 
This quotation does not explicitly state, but rather implies, that Hungarian folk music did not feature in the rudimentary musical experiences of the young Kurtág and his wife, and that both of them sought help from the more proficient Ligeti. Kurtág does not mention that on initiating his friends into the science of ethnomusicology, Ligeti relied on Béla Bartók's 1924 classification of Hungarian folksongs. ${ }^{2}$ In an extended interview with Kurtág in 2007-2008, Bálint András Varga suggested that he must have had personal experiences with folk music. ${ }^{3}$ First Kurtág denied this assumption and stated rather that he only knew folk music from editions, although he listened to discs many times. ${ }^{4}$ Upon further enquiry regarding his relationship with folk music, he divulged his 1951 experiences collecting folk song:

The Institute of Popular Education sent us young composers to collect folk music on a voluntary basis. I went to the village of Sárpilis in Tolna County. My actual assignment was to "patronize" (to use a phrase current at the time) the local amateur choir led by István Bogár. They had collected the local folk songs and fashioned an attractive program out of them. I also had time left to collect folk music myself. At first go, I only heard uninteresting, dull stuff; what I was after were old-style folk songs. I hummed a bagpipe strain to indicate what I had in mind - whereupon Auntie Éva Kurdi, an old peasant woman, embarked on singing one after the other, submerging me with an avalanche of vulgar rhymes. It was folklore of a kind, perhaps, but was certainly of no scientific interest. In any case, I gave the material to the Institute of Popular Education but never made it a subject of scholarly study. ${ }^{5}$

This anecdote not only recounts the nature of folk music collecting as compulsory social work in the Stalinist era in Hungary (exemplified also by the patronage of an amateur choir), but that these firsthand experiences failed to materialize the Bartókian "clear spring" of peasant culture for Kurtág. Ironically, he became acquainted with low forms of folklore, namely the world of obscene peasant literature.

Kurtág's account can be regarded as symbolizing his artistic relationship with folk music. In 1973, however, he had the opportunity to become acquainted with Hungarian folk music in Transylvania, namely in Gyimes (in Romanian: Ghimeş) and Szék (Sic): locales revered by folk music researchers by virtue of their archaic musical styles. Through the good offices of Júlia Szegö, a folk music researcher of Kolozsvár (Cluj), he met a folk musician named Mihály Halmágyi. The violinist's

2. Béla BARTÓK, A magyar népdal [The Hungarian folk song], ed. by Dorrit RÉVÉSZ (Budapest: Zeneműkiadó, 1990) (= Bartók Béla írásai, vol. 5).

3. VARGA (ed.), Kurtág, 42.

4. Ibid.

5. Ibid. 
performance style inspired Kurtág to compose, as an homage to him, a piano piece for four hands in the fourth volume of his series Játékok [Games], commenced in the same year. ${ }^{6} \mathrm{He}$ also listened to the rare recording of a peasant's performance: an elderly man singing the old-style version of the folksong Szerelem, szerelem, játkozott gyötrelem [Love, love, damned anguish]. This experience inspired him to write a piano piece with the same title for the second volume of Játékok, and a further transposed version for the third (Hommage à Farkas Ferenc).

Due to Bartók and Kodály's high esteem of the region, the concept of Hungarian folk music in Kurtág's, and many other Hungarian intellectuals', thinking was inherently linked to Transylvania. It is also conventional that Kurtág includes the instruction "Molto rubato" in Hommage à Halmágyi Mihály, and "Parlando" in the two Szerelem, szerelem compositions. Rubato and parlando, and particularly parlando rubato, denote a precisely definable performing style in Hungarian folk music: an almost rhythmically free interpretational manner in which the melody is adjusted to the lilt of speech. "Tempo giusto," which appears as a contrast in the interludes of Szerelem, szerelem, játkozott gyötrelem, for example, is the antithesis of parlando rubato. The use of parlando rubato is found commonly in old-style Hungarian folk music, especially with regard to laments.

The aforementioned pieces of Játékok suggest that Kurtág must have been aware of parlando rubato in the context of folk music. Bartók's 1924 monograph concerned with Hungarian folksong also elucidates the characteristics of this interpretational manner and its significance to Hungarian folk music. ${ }^{7}$ It is, however, paramount that Kurtág had the opportunity to become acquainted with authentic folk music practice, especially the instrumental folk music of Transylvania. In any case, it was shortly after the táncház [dance house] movement turned the Hungarian intellectuals' attention to Transylvanian folk music in $1972 .{ }^{8}$ Nonetheless, Kurtág never presented folk music in its original form in his compositions, as Zoltán Farkas revealed in an essay exploring the use of folk elements in the works of Ligeti and Kurtág. ${ }^{9}$ Furthermore, the influence of folk music and Bartók's music cannot be separated. The reception of folk music is generally only one aspect of the reception of Bartók's auvre. Accordingly, interpreting the influence of folk music in Kurtág's compositions, as Farkas noted, is methodically problematic. ${ }^{10}$

It is noteworthy that Kurtág had already sought to define himself as a Hungarian composer at the time of writing Bornemisza Péter mondásai [The sayings of Péter Bornemisza] (1963-1968). As Rachel Beckles Willson notes, he conscious-

6. Ibid., 43 .

7. BARTÓK, A magyar népdal, 19.

8. Rachel BECKLES WILLSON, Ligeti, Kurtág, and Hungarian Music during the Cold War (Cambridge: Cambridge University Press, 2007), 129.

9. Zoltán FARKAS, "The Influence of Hungarian Folk Music in the Oeuvre of G. Kurtág and G. Ligeti," in Gestes, fragments, timbres: la musique de György Kurtág en l'honneur de son 80e anniversaire, ed. by Márta GRABÓCZ and Jean-Paul OLIVE (Paris: L'Harmattan, 2008), 51-70.

10. Ibid., 57.

Studia Musicologica 60, 2019 
ly established his image as a national composer, following Bartók's model, in a cultural environment where many rival interpretations competed with regard to "Hungarianness" in music. ${ }^{11}$ The reception history of this piece confirms that Hungarian musical life was also intent on framing Kurtág's works within this context. ${ }^{12}$ This is demonstrated above all by references to his Russian works, in which the use of the cimbalom, a specifically Hungarian instrument, was interpreted as Kurtág's hidden marker of "Hungarianness" in a foreign context. The question is, however, justified: what concrete signs in Kurtág's compositions verify his consciously established musical "Hungarianness" at a time when he deliberately took a step towards the international musical landscape in the form of his Russian cycles? My study focuses therefore on the Hungarian vocal works written between 1973 and 1984, as well as the Kafka-Fragmente written successively (1985-1987), though in German.

Although Kurtág emphasized in a statement that composing was a "strictly private affair" for him, ${ }^{13}$ his compositional sketches and drafts provide an important insight into the musical background of his finished compositions. He already concealed hints of folk music in the sketches of Négy capriccio [Four capriccios] composed in 1969-1970, particularly regarding the second movement (Tour Saint Jacques), where Kurtág used the orchestral motto of the movement to create a longer orchestral passage. One version of this passage bears Kurtág's remark: "lament over impotence - parlando rubato." ${ }^{14}$ Kurtág's note sheds light on the fact that he consciously links the style of the laments to the instruction parlando rubato. Simultaneously, the remark relating to impotence denotes the textual reference to the lack of a man's potency, the fullness of man. István Bálint's poems in Four Capriccios are symbolically or ironically preoccupied with sexuality, or rather the lack of it, and their fragmentary and slippery texts presumably evoked Kurtág's memories of peasant obscenity in the 1950s. The idealization of parlando rubato thereby became the symbol of something lacking.

Kurtág already began to work on the second movement of his op. 25, Három régi felirat [Three old inscriptions] at the time of completing The Sayings. ${ }^{15} \mathrm{It}$ seems that as far as text and musical characteristics are concerned, the Székely mángorló, 1792 [Transylvanian Székely mangle, 1792] is a direct continuation of the style he developed in The Sayings. In one sketch dating from December 1967, Kurtág noted down other epitaphs with texts very similar to the Transylvanian Székely Mangle. ${ }^{16}$ All of them can be characterized by a particular line structure,

11. BECKLES WILLSON, Ligeti, Kurtág, 129-134.

12. Rachel BECKLES WILLSON, György Kurtág: The Sayings of Péter Bornemisza, Op. 7. A 'Concerto' for Soprano and Piano (Aldershot: Ashgate, 2003), 130-144.

13. VARGA (ed.), Kurtág, 34.

14. Paul Sacher Stiftung, Basel, György Kurtág Collection, 0315-0083.

15. See Sketchbook no. 14 in the Kurtág-collection of the Paul Sacher Stiftung, Basel. The earliest sketches were written down in 1967.

16. Paul Sacher Stiftung, Basel, György Kurtág Collection, 0551-0556. 
the so-called Hungarian alexandrine line, which is based on 12 syllables divided in the middle. This characteristic poetic form, which appears both in folk literature and music and also in "high" poetry, was analyzed in detail by Zoltán Kodály in his 1920 study, Árgirus nótája [Árgirus's song] and became well-known throughout Hungary ${ }^{17}$ Kurtág would have been familiar with Kodály's study, and thereby the significance of this poetic form. Nevertheless, he copied a poem in which the words parodied or paraphrased Kodály's Psalmus Hungaricus. ${ }^{18}$ Though the word "pride" (kevélység) appears in both pieces, in Kurtág's work, the hero taunts his home country, patrons and eternal values, while in Kodály's work the outside world turns against the ethical, good hero. Kurtág's sketches contain one further clue revealing the composer's interest in "Hungarianness" in music: he enters elements of the so-called "Hungarian scale" under the text, though the scale rapidly becomes inverted to create a whole tone-scale (Facsimile 1).

The text of the Transylvanian Székely Mangle is the monologue of a wife murderer. This topic has peculiar piquancy if we consider that Kurtág offered the cycle to his wife Márta for their fortieth wedding anniversary. The husband's motive for killing his young wife must have invoked personal memories in the Kurtág couple. As Kurtág admitted, Márta did not let him touch her neck for a long time for fear her husband might strangle her. ${ }^{19}$ The song concentrates largely, rather, on the husband's state of mind. In the middle of the song, where the "Molto rubato" instruction appears, the killer, reciting a so-called 1:2 model scale,$^{20}$ tells us that he "sits heavy in the stocks at Kászonszék" (Kászonszéken ülök nehéz kalodában), that is, he is languishing in jail. Kurtág again uses the rubato instruction when the lack of something - the lack of freedom - becomes apparent (Example 1).

In the pieces written almost in succession in the 1980s - József Attila töredékek [Attila József fragments] (op. 20), Seven Songs (op. 22), Eight Choruses (op. 23) the symbol of a lacking element and the instructions parlando or rubato are closely linked. The most telling example of this connection is the fourth song of op. 22, Ajtón lakattal [With a lock on the door], in which the whole movement is required to be played "Rubato, parlando, con moto." Amy Károlyi's poem focuses on the lack of personal and artistic freedom: its beginning ("On the border of the permitted and prohibited") is a conscious allusion to public policy, the Kádár regime's well-known principle of operation, which included works in one of the categories of the "three Ps" (propagated, permitted, prohibited).

17. Zoltán KODÁLY, “Árgirus nótája” [Árgirus’s song], in id., Visszatekintés. Összegyüjtött írások, beszédek, nyilatkozatok [Recollection. Collected writings, speeches, statements], ed. by Ferenc BÓNIS (Budapest: Zeneműkiadó, 1974), vol. 2, 79-90 (= Magyar zenetudomány, vol. 6).

18. Paul Sacher Stiftung, Basel, György Kurtág Collection, Sketchbook no. 14, 0551.

19. VARGA (ed.), Kurtág, 64.

20. According to Ernő Lendvai's terminology of Bartók's music. Ernő LENDVAI, The Workshop of Bartók and Kodály (Budapest: Zenemükiadó, 1983). 
FACSIMILE 1 A sketch of a melody from the Sketchbook of Székely mángorló (György Kurtág Collection, Sketchbook no. 14, 0553) Reproduced by kind permission of the Paul Sacher Stiftung, Basel

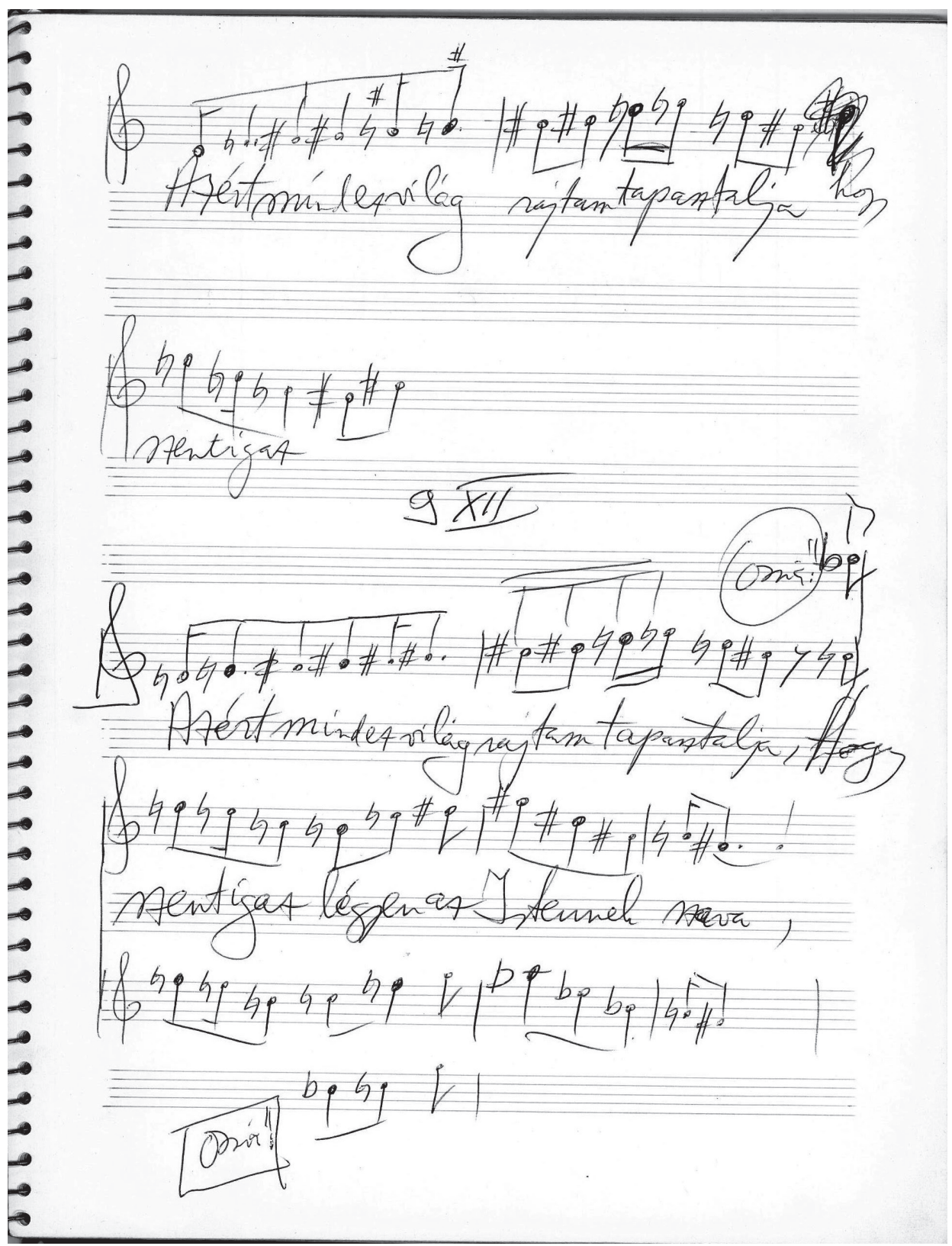


ExAmPLE 1 Kurtág, Székely mángorló, the section beginning with "Kászonszéken ülök..." (C) Copyright by Universal Music Publishing Editio Musica Budapest

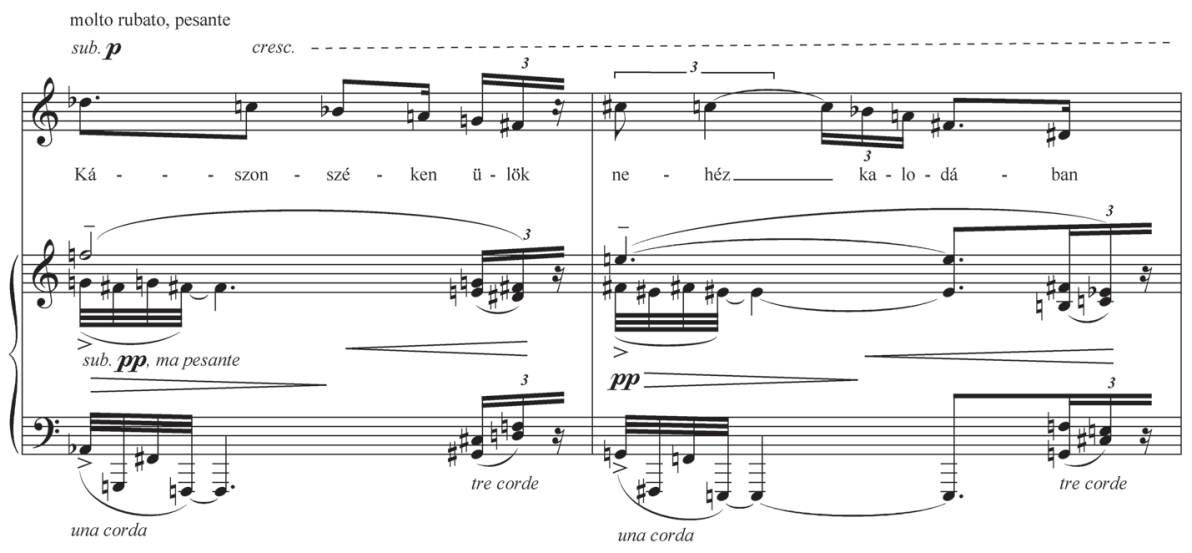

There is, however, a musical trait characterizing this song and his other contemporary vocal compositions: Kurtág's tunes increasingly assume a melodic character, and this melodiousness sometimes reaches back to Gregorian chant, for example in the Lesz lágy hús mellé kalarábé movement of the Attila József Fragments. Kurtág himself does not differentiate Gregorian chant from folksong melodies when he mentions that the "do-re-mi" melody of A puszta létige szomorúsága movement of the S. K. - Emlékzaj [S. K. - remembrance noise] (op. 12) is the same formula which opens Lesz lágy hús. He refers to a "Gregorian or folk-song-like recitative." ${ }^{21}$ Both melodies refer unambiguously to Gregorian chant. The first notation of Lesz lágy hús in Kurtág's sketches preserves the original, diatonic musical idea which was eventually transposed in the final version. Kurtág does not use the instruction parlando in $S$. K. - Remembrance Noise but employs this instruction in Lesz lágy hús, hinting once again at the lack of a man who is no longer alive.

It is worth returning to Kurtág's statement in which he eliminates the difference between the melodiousness of Gregorian chant and folksong. László Dobszay's book on the style of folk laments appeared in 1983, a year after the composition of the Attila József Fragments. ${ }^{22}$ In this volume the musicologist, founder and conductor of the ensemble Schola Hungarica, demonstrated convincingly the theory that Gregorian chant was the source of one of the oldest layers of Hungarian folk music. This idea served as an inspiration to many Hungarian composers, particularly to those who, like Kurtág, were active members of Dobszay's choir. ${ }^{23}$

21. VARGA (ed.), Kurtág, 10.

22. László DOBSZAY, A siratóstílus dallamköre zenetörténetünkben és népzenénkben [The melodic types of the lament songs in our music history and folk music] (Budapest: Zenemükiadó, 1983).

23. BECKLES WILLSON, Ligeti, Kurtág, 220. 
The fourth movement of Eight Choruses (op. 23), Koan bel canto uses a similarly melodic opening line in which one of the characteristic types of Hungarian folk songs is evident (Example 2). Both the first instruction of the movement ("Parlando, molto rubato") and the subtitle of the piece ("Hallgató nóta," a song for listening to, not for dancing) refer to folk traditions. Although hallgató nóta does not form part of the repertoire of peasant music, it is a well-known form of the popular art song tradition. Nevertheless, the rhythm and the movement of the melody recall a Hungarian folk song type. One of Kurtág's sketches of this movement retains a diatonic version of the final melody, resembling rhythmically one of the new style folk song types of Hungarian folk music (Facsimile 2).

ExAmPle 2 Kurtág, Koan bel canto, beginning

(C) Copyright by Universal Music Publishing Editio Musica Budapest

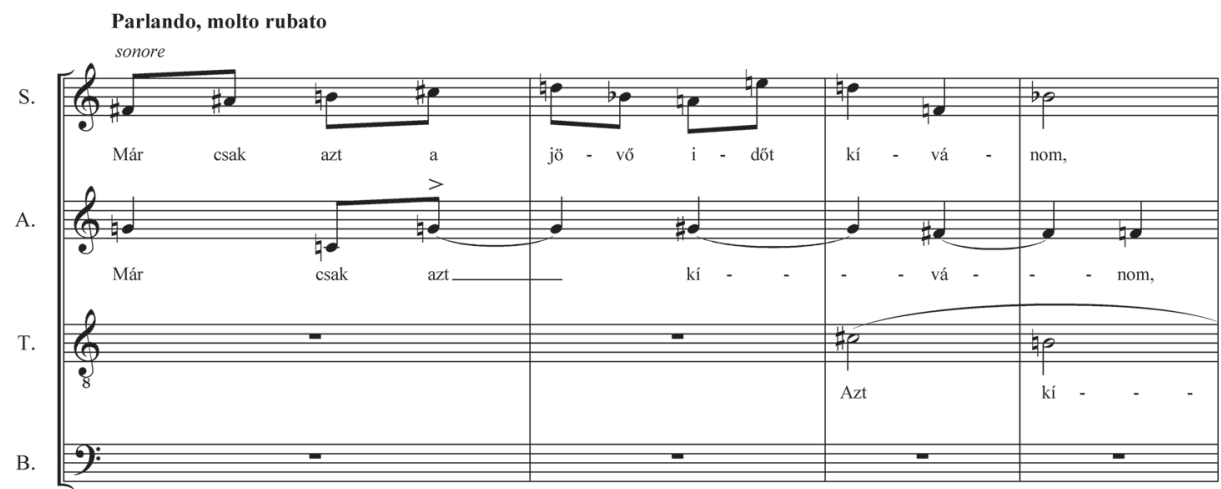

Kurtág must have decided to create a chromatic version from the original diatonic melody at a later phase of the compositional process. He simultaneously sought to preserve the folk song character, in a later sketch adding to "Parlando, molto rubato:" "Alkalmazkodó ritmusban" [in adaptive rhythm]. ${ }^{24}$ This instruction is extremely common in editions of Hungarian folk songs, and reinforces the parlando rubato direction. The title of the poem, Koan bel canto, further evoked the use of a folk-song-like melody. Kurtág combined the bel canto ideal of the nineteenth-century operatic style with folk singing practice. The identification of these two styles is in harmony with Bartók and Kodály's interpretation. Nevertheless, Kurtág approaches this reading with irony, partially, because his (and Dezső Tandori's) bel canto is an Asian version (a choan), and partially because the "Parlando, rubato" instruction again evokes lack: a lack of the present in a poem where the past and the future confusingly intertwine. 
Facsimile 2 A sketch from the Sketchbook of the Eight Choruses

(György Kurtág Collection, Sketchbook no. 56, 0740)

Reproduced by kind permission of the Paul Sacher Stiftung, Basel

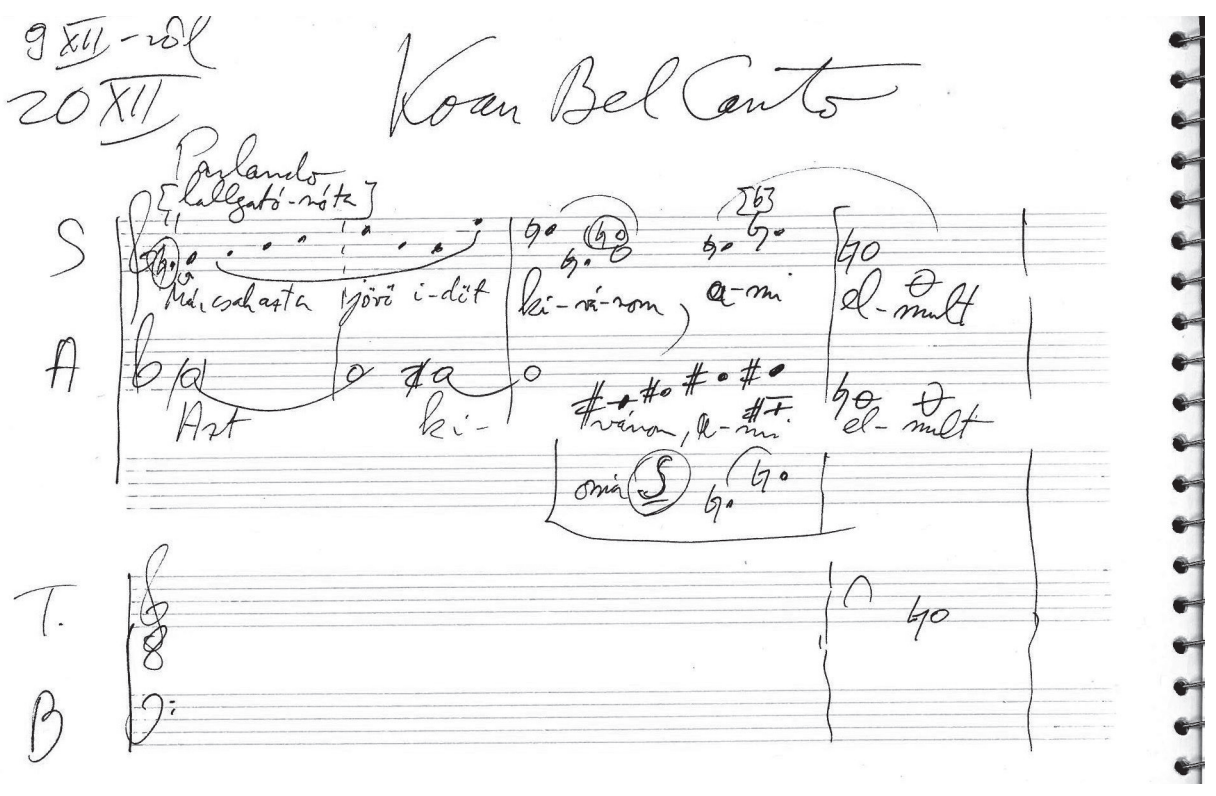

Further to folk music references in works derived from Hungarian texts, there are also allusions to folk music and "Hungarianness" in the sketches of the Kafka-Fragmente. Kurtág sought to weave a mark of "Hungarianness" consciously into this piece (akin to the use of cimbalom in his Russian pieces). There is a Kafka fragment among Kurtág's sketches ("Ich habe niemals die Regel erfahren") which was omitted from the final version of the piece. Four sketches of this planned movement preserve Kurtág's instruction regarding the syllable "Erfahren" implying that it must be sang "mit fremdem Akzent, magyarosan" [with a foreign accent, in a Hungarian manner] (Facsimile 3). This reference to Hungarian accent is, of course, an ironic explanation of the text: someone who speaks with a foreign accent does not comply with the rules. There are, however, sketches in which Kurtág refers to an alternative interpretation of the text. He notes under the title: "a szarvassá lett fiú éneke" [the song of the boy turned deer] - a clear reference to Bartók's Cantata profana and the related dilemma of choice between freedom and restraints.

In sketches of the last movement of the Kafka-Fragmente (Es blendete uns die Mondnacht...) Kurtág alludes to the folk song Szerelem, szerelem, játkozott gyötrelem (Facsimile 4). He adds to the final word of the phrase ("Wir krochen durch den Staub"): "És most a Szerelem, szerelem, játkozott gyötrelem!" [And now: Szerelem, szerelem, játkozott gyötrelem!]. At this moment the violin, and 
FACSIMILE 3 "Ich habe niemals..." - sketch for a planned movement for Kafka-Fragments (György Kurtág Collection, 0316-0982) Reproduced by kind permission of the Paul Sacher Stiftung, Basel

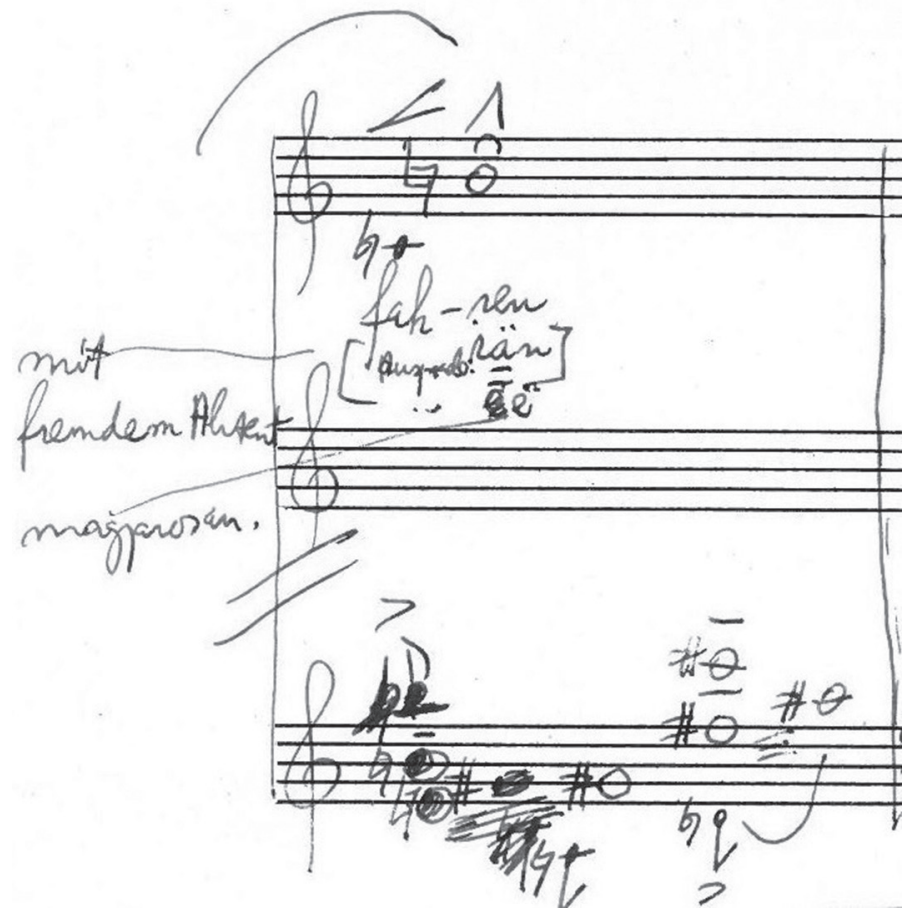

later the soprano, initiate the core notes of the piano piece from Játékok (D-Fsharp-G) as a symbol of love, which here pertains to "cursed anguish," both in terms of reality and in reference to the folk song. Kurtág entered a further note at the bottom of the manuscript: "Megnézni a heg. rapszódiák lassújában nincs-e használható anyag!" [Check if there is any usable material in the slow part of the violin rhapsodies!] Kurtág here likely refers to Bartók's two Rhapsodies for violin and piano from 1928. At this stage, the final version did not quote from Bartók's works. In an earlier section of the piece, however, Kurtág evokes the style of the slow part of Bartók's Rhapsody no. 2 before the imagery of crawling snakes, where the violin suddenly commences a diatonic passage (Example $3 a$ ).

Once again, Kurtág opted for "Lento, rubato" here, which subsequently returns, as indicated by the "a tempo" instruction, upon the soprano's repetition of the diatonic formula beginning at the word "Wir" (Example 3b). The two soloists pass on to each other the motive, similarly to the interplay between piano and violin in Bartók's composition. Kurtág's "rubato" section divides the form. Having looked into the distance, the eyes look down towards the dust where the pair of 
FACSIMILE 4 "Ich habe niemals..." - sketch for a planned movement for

Kafka-Fragments (György Kurtág Collection, 0316-0991)

Reproduced by kind permission of the Paul Sacher Stiftung, Basel

VIIT685

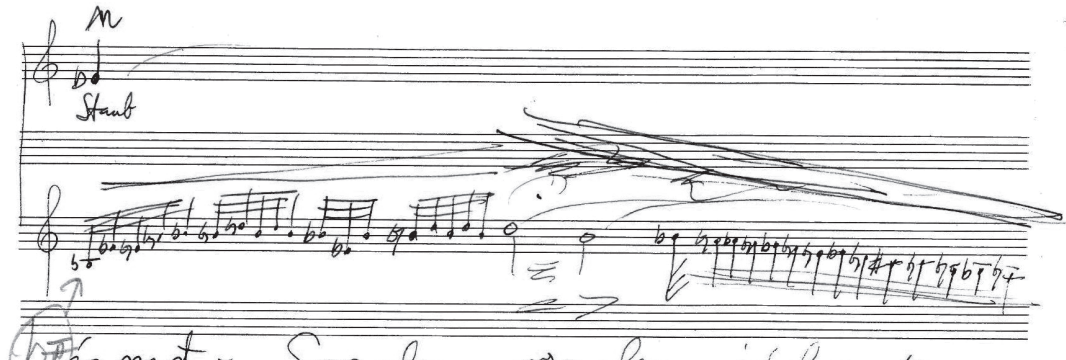

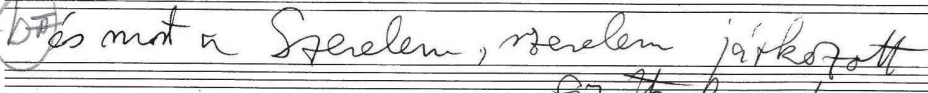
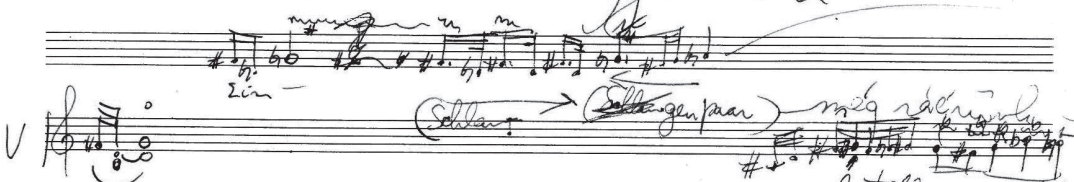

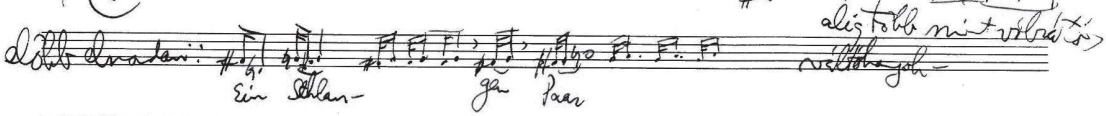

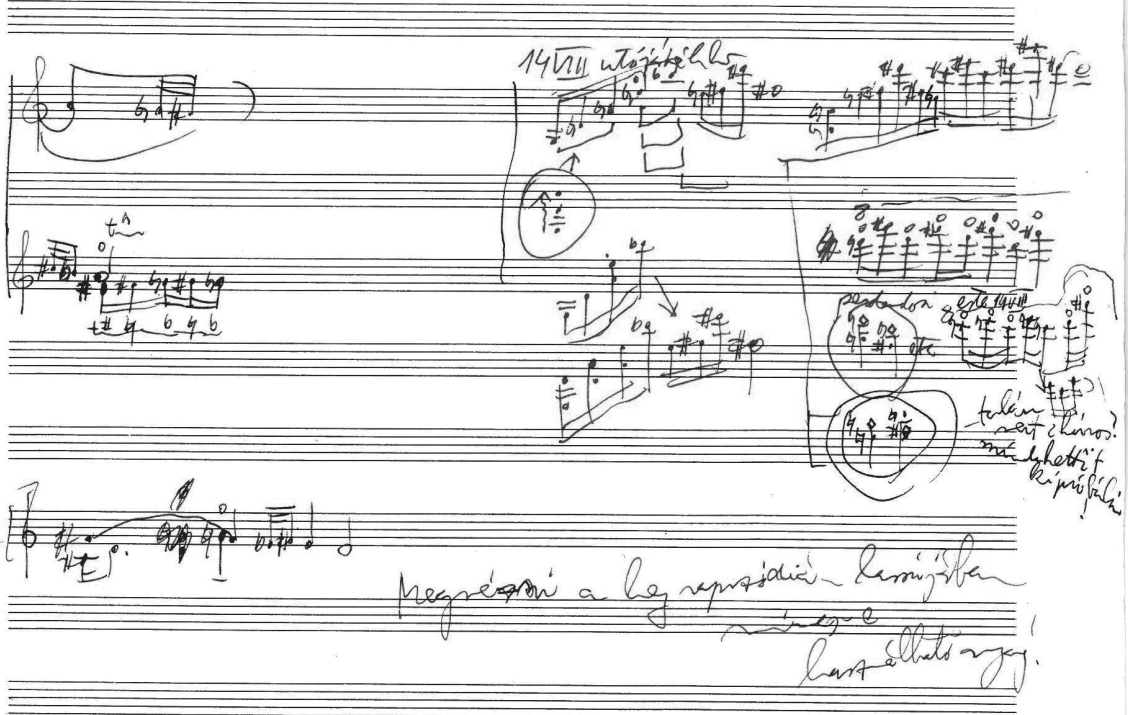


ExAmPle 3А-в Kurtág, Kafka-Fragments, "Es blendete uns...”, Bartók-Rhapsody allusion (C) Copyright by Universal Music Publishing Editio Musica Budapest
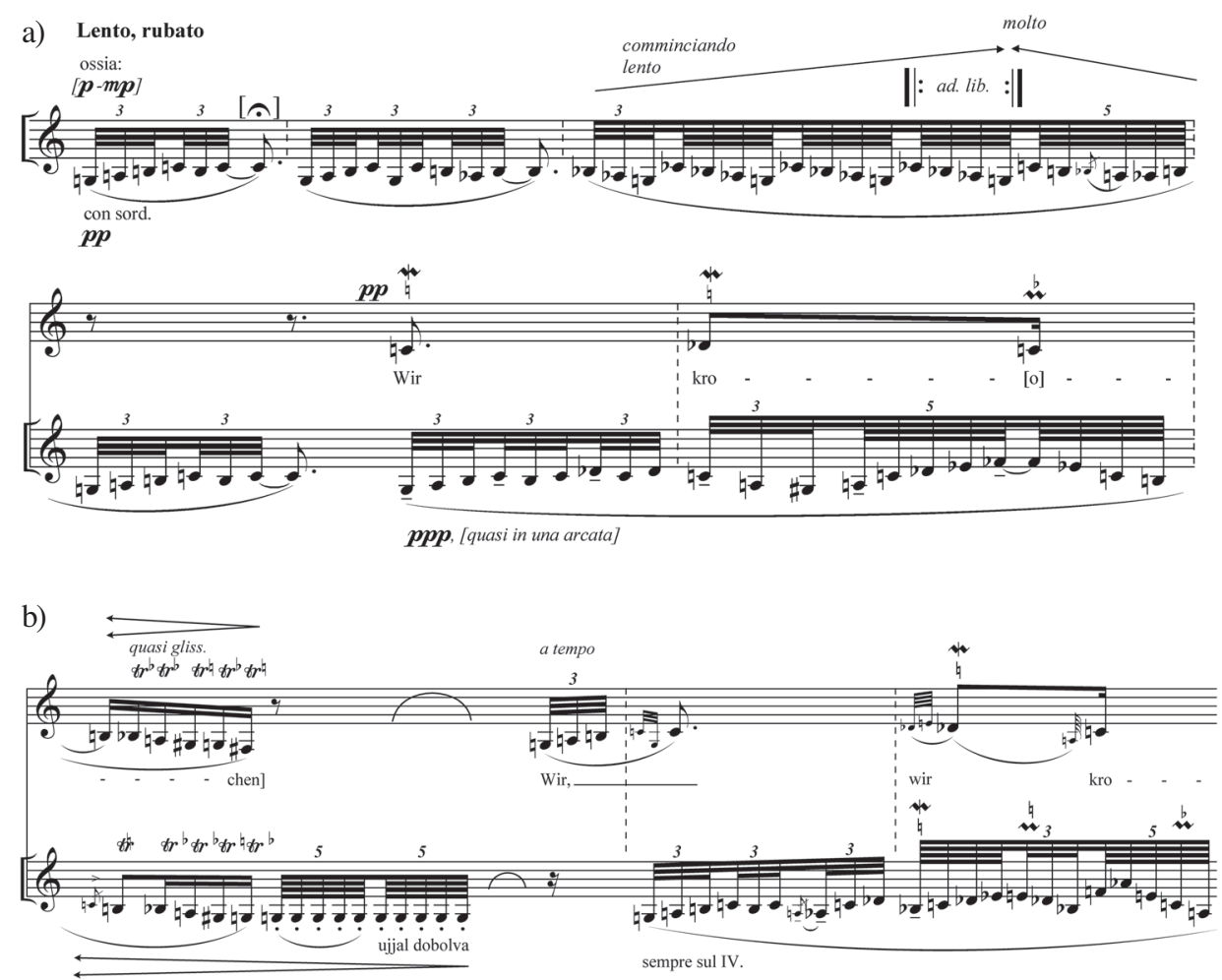

snakes are crawling. This antithesis reveals the lack, the impossibility of the physical and spiritual ascent of the snakes.

The slow part of a rhapsody appears in another movement of the Kafka-Fragmente, namely in Szene in der Elektrischen (III/12), in the form of the mistuned violin's melody accompanied by a single violinist. Kurtág's motto at the outset of this movement includes a Hungarian dance, a csárdás: "Ich bat im Traum die Tänzerin Eduardowa, sie möchte doch den Csárdás noch einmal tanzen." [In a dream, I asked the dancer Eduardowa if she would kindly dance the csárdás once more.]

The form of the twelfth movement does not display resemblances with the csárdás, which is commonly based on a sequence of accelerating dances. The Szene in der Elektrischen is tripartite in form. The two A sections evoke the slow passage of a rhapsody, while the B section quotes a waltz, Josif Ivanovici's Valurile Dunării, in a heavily distorted form. It is illuminating, however, that Kurtág does not use the instruction parlando rubato in the A sections, so it is possible 
that the violinists accompanying the dancer Eduardowa are not Hungarians, but Romanians. Not only are they playing a Romanian waltz, but the first violin's melody, with its hiccup-like turns in the slow parts, also resembles the improvised formula of a hora lungă (Example 4). Eduardowa, her violinists, and her audience suffer no deprivation: they appear satisfied, even though Kurtág treats the patently

EXAMPLE 4 Kurtág, Kafka-Fragments, "Szene in der Elektrischen,” hora lungă

(C) Copyright by Universal Music Publishing Editio Musica Budapest
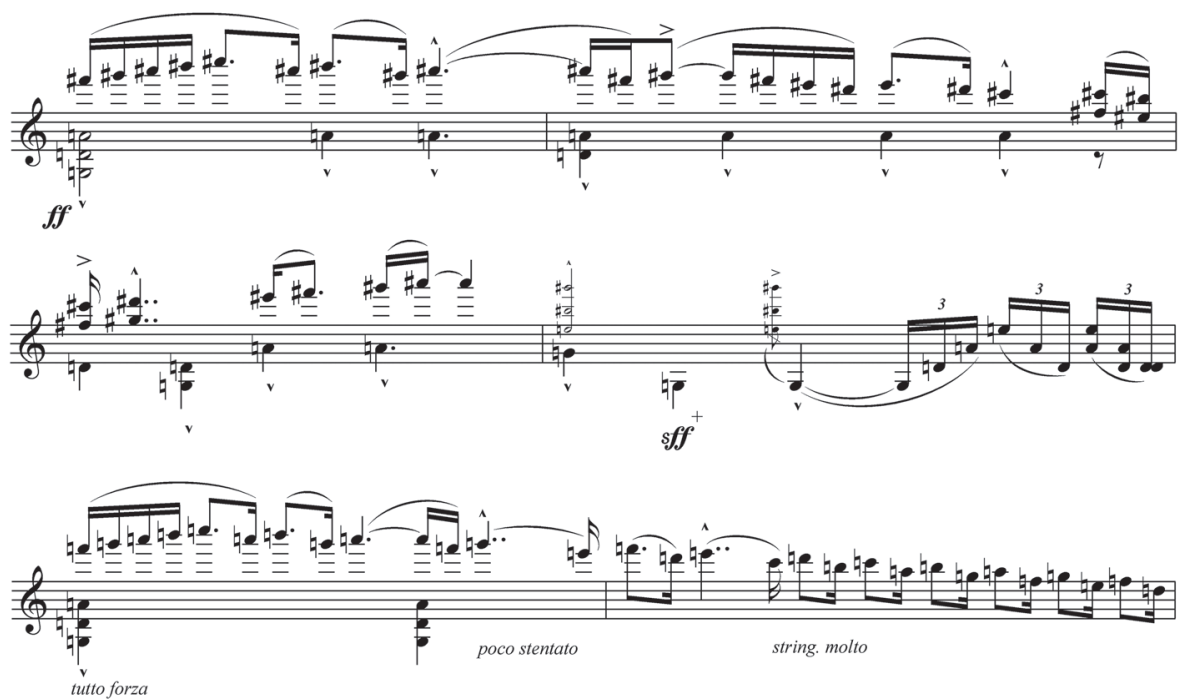

strange events with perceptible irony. Nevertheless, one can assume that satisfaction cannot be expressed through Hungarian tones.

The parlando rubato style, which signifies freedom of interpretation in Hungarian folk music, appears as a symbol of the lack of personal and artistic freedom in György Kurtág's musical world. Kurtág distances himself ironically from Bartók and Kodály's Hungarian musical tradition, as the aforementioned examples have shown; his use of these elements and the references to Bartók and Kodály represent the impossibility of fulfillment. His musical "Hungarianness" is a revealing exercise in the art of lack.

Open Access. This is an open-access article distributed under the terms of the Creative Commons Attribution 4.0 International License (https://creativecommons. org/licenses/by/4.0), which permits unrestricted use, distribution, and reproduction in any medium, provided the original author and source are credited, a link to the CC License is provided, and changes - if any - are indicated. 
